\title{
Wood-Cement Board Reinforced with Steel Nets and Woven Hemp Yarns: Physical and Mechanical Properties
}

\section{Drvno-cementna ploča ojačana čeličnom mrežom i tkanom konopljom: fizikalna i mehanička svojstva}

\author{
Original scientific paper • Izvorni znanstveni rad \\ Received-prispjelo: 1. 6. 2016. \\ Accepted-prihvaćeno: 11. 5. 2017. \\ UDK: $630 * 861.232 ; 630 * 812$ \\ doi:10.5552/drind.2017.1631
}

\begin{abstract}
The aim of this study was to improve physical and mechanical properties of wood-cement boards and to determine optimum content of cement in the formulation. Hence, boards were reinforced with steel nets and woven hemp yarns adding cement to the dry mass of wood in the ratio of 2.5:1, 2.75:1 and 3:1. Physical and mechanical properties of wood-cement boards, such as water absorption (WA) and thickness swelling (TS) after 2 and 24 hour immersion in water, bending strength (MOR), modulus of elasticity (MOE) and internal bond strength (IB), were determined according to EN Standards. Results showed that reinforcement of boards with steel nets and 3 parts of cement added to the dry mass of wood improved all physical and mechanical properties. Properties of these boards showed a similar trend to the values of EN 634-2:2007 standard (specifications of cement bonded particleboards), except for modulus of elasticity, which was lower than minimum requirement.
\end{abstract}

Key words: wood-cement board, cement content, steel nets, hemp yarns, physical and mechanical properties.

SAŽETAK • Cilj istraživanja bio je poboljšati fizikalna i mehanička svojstva drvno-cementnih ploča i odrediti optimalan sadržaj cementa u njima. Ploče su ojačane čeličnim mrežama i tkanom konopljom. Sadržaj cementa u proizvedenim pločama bio je u omjeru 2,5:1; 2,75:1 i 3:1 u odnosu prema suhoj masi drvnog materijala. Fizikalna i mehanička svojstva drvno-cementnih ploča kao što su apsorpcija vode (WA) i bubrenje po debljini (TS) nakon 2 i 24 sata namakanja uzoraka u vodu, čvrstoća na savijanje (MOR), modul elastičnosti (MOE) $i$ unutarnja čvrstoća vezanja (IB) određeni su prema europskim normama. Rezultati su pokazali da su ojačanjem ploča čeličnim mrežama i dodatkom trostruko veće količine cementa od suhe mase drvnog materijala poboljšana sva fizikalna i mehanička svojstva ploča. Svojstva tih ploča imaju vrijednosti slične vrijednostima što ih propisuje norma EN 634-2: 2007 (obilježja iverica s cementom), osim za modul elastičnosti, koji je za istraživane ploče bio manji od minimalno zahtijevanoga u normi.

Ključne riječi: drvno-cementna ploča, sadržaj cementa, čelične mreže, konoplja, fizikalna i mehanička svojstva

\footnotetext{
${ }^{1}$ Author is associate professor at Shahid Rajaee Teacher Training University, Faculty of Civil Engineering, Department of Wood Science and Technology, Tehran, Iran.

' Autor je izvanredni profesor Učiteljskog sveučilišta Shahid Rajaee, Građevinski fakultet, Odjel za znanost o drvu i drvnu tehnologiju, Tehran, Iran.
} 


\section{INTRODUCTION}

\section{UVOD}

Due to increasing population and environmental awareness, demand for light, cheap and more ecofriendly materials is increasing. Because of heaviness and low bending strength of concrete, building materials could not be used as large panels and prefabricated panels in construction. Furthermore, the use of cement boards reinforced with asbestos, which is still produced in some countries, cannot meet the environmental requirements. In this regard, cement-bonded composites reinforced with natural fibers or wood particles are presented as a valuable construction material. One of the problems in producing wood cement boards is the decrement in speed of cement hydration after the addition of wood particles. Consequently the alkali-soluble compounds, water-soluble hemicellulose and wood extractives limit and postpone cement curing, therefore reducing the resistance of wood-cement panels (Catarina et al., 2006; Miller and Moslemi, 1991; Nazerian and Sadeghiipanah, 2013; Wei et al., 2000). Due to embrittlement characteristics of cement and low tensile strength, these boards are susceptible to fail under different loadings. So reinforcing these panels with different materials seems necessary for improving their physical and mechanical properties.

Nazerian and Sadeghipanah evaluated cementbonded particleboards manufactured from a mixture of wheat straw and poplar. They reported that cement composites, with bending strength of around $12.5 \mathrm{MPa}$ and internal bond strength of about $0.28 \mathrm{MPa}$, can be made by using wheat straw as a reinforcing material. According to the results, the use of straw particles in the panels of up to $11.5 \%$ satisfied the minimum requirements of EN 312 (2003) for IB and MOR. Also, it was determined that the amount of $4.95 \%$ of calcium chloride (by cement weight) could improve mechanical properties of the panels meeting the minimum requirements of $\mathrm{EN}$ 312 (Nazerian and Sadeghipanah, 2013). Investigation of properties of cement-bonded wood-wool boards made from a mixture of eucalyptus and poplar showed that the addition of wood to cement clearly reduced the maximum hydration temperature and increased the time to reach the maximum temperature. Test results showed that boards made of poplar wood-wools had superior properties compared to those made of eucalyptus and mixed wood-wools. The presence of eucalyptus in the wood mixture typically resulted in a decrease of mechanical properties. It has been noted that the amount of $5 \%$ of $\mathrm{CaCl}_{2}$ by cement weight can be beneficial for cement curing (Ashori et al., 2011).

Three-layered cement-bonded boards (CBBs) produced from wastepaper and sawdust at cement/particle ratios of 3.0:1 and 3.5:1 was suitable for building construction such as paneling, ceiling and partitioning (Fuwape et al., 2007).

According to Aggarwal et al. (2008), agro-based cement composites, with bending strength $>9.0 \mathrm{MPa}$ and internal bond strength $>0.6 \mathrm{MPa}$, could be made using arhar stalks as reinforcing material and were found to satisfy the minimum requirements of the International Standard, ISO: 8335-1987 (Aggarwal et al., 2008).

The aim of all these studies was to improve physical and mechanical properties by use of lignocellulosic materials. Another way to improve physical and mechanical properties of wood cement boards is to reinforce them by steel nets and hemp yarns but no research has yet been done in this field. In the study related to medium density fiberboard (MDF) panels reinforced by metal (stainless steel with a mesh size of $25 \mathrm{~mm}$ ) and woven polymeric nets, it has been determined that boards reinforced by thin metal nets (with string diameter of $0.7 \mathrm{~mm}$ ) showed the highest MOR with a $105 \%$ increase; while the highest MOE and impact strength were determined in the boards reinforced by thick metal nets (with string diameter of 1.12 $\mathrm{mm}$ ), which were primarily embedded in $112 \%$ and 79 $\%$ epoxy resin. The highest tensile strength was also determined in boards reinforced by thick metal nets. Boards reinforced by woven polymeric nets showed lower strength than those reinforced by metal nets (Mohebbi et al., 2011).

Xiong et al. studied ribbed roof panels made of high-density wood shaving-cement boards reinforced with steel strips. They reported that employing wood shavings increased flexural strength, load-carrying capacity, stiffness, and plastic property of cement based panels compared to panels without wood shavings (Xiong, 1996).

According to Dimakis et al. (2006), using reinforcing strings of metal, rubber, plastic, glass fibers, carbon fiber and even graphite in wood based composites increased significantly impact load resistance, toughness, and also tensile strength (Dimakis et al., 2006).

The aim of this research was to investigate the issue of reinforcement of wood cement boards. As it is well known, when a board is under bending load, the highest tensile stress occurs at the bottom side of the board and the highest compression stress occurs at the top side of the board. If the reinforcement is placed on the sides where high stress occurs, the strength of the board should increase. Therefore, reinforcement of wood cement boards was studied by placing two types of steel and woven hemp yarn nets as reinforcement at the critical points of the board, on top and bottom sides.

\section{MATERIALS AND METHODS} 2. MATERIJALI I METODE

Wood particles used in this study were obtained by planing poplar wood. Wood particles were dried to $3 \%$ moisture content and packed in plastic bags, to be ready for laboratory tests. The cement used in manufacturing the boards was Portland type II produced by the Abic factory in Qazvin. In order to accelerate curing of the cement in the mixture of cement and wood particles, $5 \%$ of calcium chloride was used to dry the cement mass. The diameter of steel wires was $0.5 \mathrm{~mm}$ and net dimensions were $25 \mathrm{~mm}$. The diameter of hemp yarns was $0.75 \mathrm{~mm}$ and the net had the same dimension as steel nets (Figure 1). 
Top layer of wood cement board gornji sloj drvno-cementne ploče

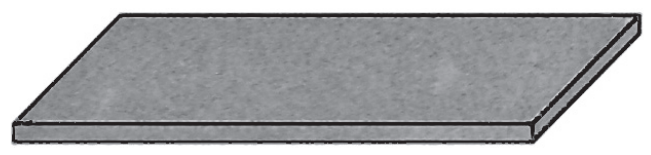

Top layer of reinforcement gornji sloj ojačanja

Core layer of wood cement board srednji sloj drvno-cementne ploče

Bottom layer of reinforcement donji sloj ojačanja

Bottom layer of wood cement board donji sloj drvno-cementne ploče
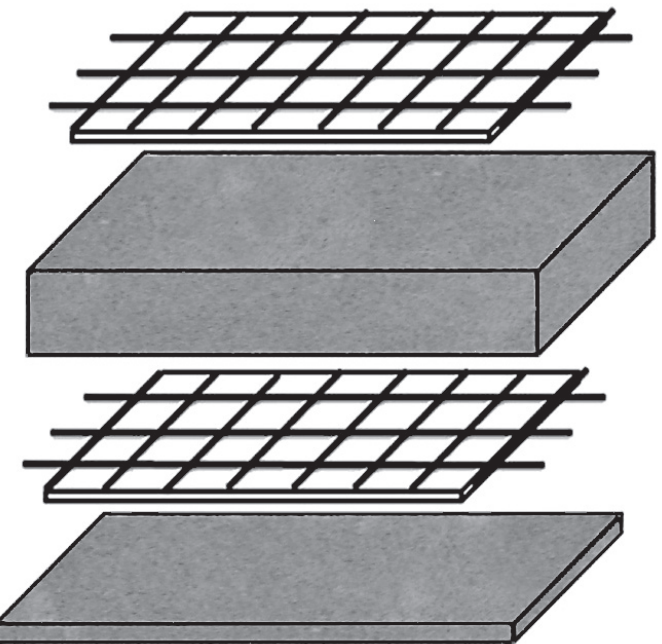

Figure 1 Configuration of the reinforcement location in the panels; the reinforcements were placed at $1 / 4$ of the board thickness Slika 1. Konfiguracija mjesta ojačanja u pločama; ojačanja su postavljena na $1 / 4$ debljine ploče

Thickness and density of the boards were $16 \mathrm{~mm}$ and $1 \mathrm{~g} / \mathrm{cm}^{3}$, respectively. Three types of boards were produced: reinforced with steel nets, reinforced with hemp yarns and non-reinforced boards (control). Three weight ratios of cement to wood particles were selected as the second variable: $2.5: 1,2.75: 1$ and $3: 1$. To minimize the influence of different factors affecting the formation of different mixtures of cement and wood particles, a steel frame with the dimension $400 \times 400 \mathrm{~mm}$ was used to produce the mat. Steel and hemp nets were placed at $1 / 4$ from the top and bottom surface of the boards (Figure 1). The prepared mat was pressed to 16 $\mathrm{mm}$ with the laboratory hydraulic press. Then, for curing and hardening the cement, steel-mould was placed in steel jaws and the press was set up. The cement panels were produced in accordance with Ashori et al. (2011).

Considering all factors, 9 treatments with 3 replicates were made, resulting in 27 wood cement boards. After removing the boards from the press, samples were conditioned in a climate chamber for at least 28 days for best curing of cement.

Samples were prepared for investigating physical and mechanical properties according to EN standard. To determine the physical properties (water absorption and thickness swelling) of wood cement boards $(50 \times 50$ $\mathrm{mm}$ ), samples were immersed in the distilled water for 2 and 24 hours according to EN 317 standard (EN 317, 1998). For the determination of $M O R$ and MOE according to EN 310, samples were prepared with the dimension $325 \times 50 \mathrm{~mm}$ (EN 310, 1999). The internal bond strength was determined on samples with the dimension $50 \times 50 \mathrm{~mm}$ according to EN 319 (EN 319, 1998).

Physical and mechanical results obtained in this study were compared with wood-cement board standard (EN 634-2, 2007).

Statistical analysis was conducted using SAS software program. Two-way analysis of variance (ANOVA) was performed to determine significant differences at the $99 \%$ confidence level. Duncan Test was used to determine the significant difference among the groups.

\section{RESULTS AND DISCUSSION 3. REZULTATI I RASPRAVA}

The results obtained from variance analysis of physical and mechanical properties of manufactured boards are shown in Table 1.

Table 1 Variance analysis of direct and joint impact of factors on physical and mechanical properties of wood cement board Tablica 1. Analiza varijance izravnoga i zajedničkog utjecaja čimbenika na fizikalna i mehanička svojstva drvno-cementnih ploča

\begin{tabular}{|l|c|c|c|c|c|c|c|}
\hline Factor / Čimbenik & MOR & $\boldsymbol{M O E}$ & $\boldsymbol{I B}$ & $\boldsymbol{T S}_{2}$ & $\boldsymbol{T S}_{24}$ & $\boldsymbol{W A}_{2}$ & $\boldsymbol{W A}_{24}$ \\
\hline Cement / Cement & $303.48^{* *}$ & $43.67^{* *}$ & $308.51^{* *}$ & $34.00^{* *}$ & $1347.07^{* *}$ & $24.39^{* *}$ & $71.18^{* *}$ \\
\hline Board type / Vrsta ploče & $2041.2^{* *}$ & $935.77^{* *}$ & $44.27^{* *}$ & $24.91^{* *}$ & $81.06^{* *}$ & $17.81^{* *}$ & $27.35^{* *}$ \\
\hline Cement× board type / Cement $\times$ vrsta ploče & $16.52^{* *}$ & $6.56^{* *}$ & $4.27^{* *}$ & $0.57^{\mathrm{ns}}$ & $5.60^{* *}$ & $0.69^{\mathrm{ns}}$ & $6.62^{* *}$ \\
\hline
\end{tabular}

MOR - bending strength / čvrstoća na savijanje; MOE - modulus of elasticity / modul elastičnosti; IB - internal bond strength / unutarnja čvrstoća vezanja; $T S_{2}$ - thickness swelling after 2 hours immersion in water / debljinsko bubrenje nakon 2 sata namakanja uzoraka u vodi; TS - thickness swelling after 24 hours immersion in water / debljinsko bubrenje nakon 24 sata namakanja uzoraka u vodi, WA - water absorption after 2 hours immersion in water / apsorpcija vode nakon 2 sata namakanja uzoraka $u$ vodi; $W_{24}$ - water absorption after 24 hours immersion in water / apsorpcija vode nakon 2 sata namakanja uzoraka $u$ vodi.

**: significant at $99 \%$ confidence level /signifikantno pri razini pouzdanosti $99 \%$; ${ }^{\text {ns. }}$ not significant / nije signifikantno. 
Table 2 Direct effect of board type on mechanical properties and Duncan grouping

Tablica 2. Utjecaj vrste ploče na mehanička svojstva i grupiranje prema Duncanovu testu

\begin{tabular}{|l|c|c|c|}
\hline Type board / Vrsta ploče & $\begin{array}{c}\text { Reinforced with } \\
\text { steel nets } \\
\text { Ploča ojačana } \\
\check{c} \text { eličnom mrežom }\end{array}$ & $\begin{array}{c}\text { Reinforced with } \\
\text { hemp yarns } \\
\text { Ploča ojačana } \\
\text { tkanom konopljom }\end{array}$ & $\begin{array}{c}\text { Non-reinforced } \\
\text { (control) } \\
\text { Ploča koja nije } \\
\text { ojačana }\end{array}$ \\
\hline Internal bond strength, MPa / Unutarnja čvrstoća vezanja, MPa & $0.402^{\mathrm{A}}$ & $0.367^{\mathrm{B}}$ & $0.363^{\mathrm{B}}$ \\
\hline Bending strength, MPa / Čvrstoća na savijanje, MPa & $13.150^{\mathrm{A}}$ & $10.35^{\mathrm{B}}$ & $9.66^{\mathrm{C}}$ \\
\hline Modulus of elasticity, MPa / Modul elastičnosti, MPa & $2895.27^{\mathrm{A}}$ & $2506.80^{\mathrm{B}}$ & $2313.25^{\mathrm{C}}$ \\
\hline
\end{tabular}

As shown, two variables (board type and cement content) had a significant direct effect $(P<0.01)$ on physical and mechanical properties.

Table 2 shows the direct effect of board type (reinforced with steel nets, reinforced with hemp yarns and non-reinforced) on mechanical properties, as well as their Duncan grouping.

As shown in Table 2, reinforcing the boards improved all mechanical properties (bending strength, modulus of elasticity and internal bond strength) and the highest strength was found in boards reinforced with steel nets compared to boards reinforced with hemp yarns and non-reinforced boards.

Table 3 shows direct effect of board type on physical properties, as well as their Duncan grouping.
According to the results shown in Table 3, the highest thickness swelling and water absorption after 2 and 24 hours immersion in water was observed in boards reinforced with hemp yarns and non-reinforced boards (control), while the lowest values were observed in boards reinforced with steel nets (grouping A). The results related to boards reinforced with steel nets, in comparison with control samples for $T S$ and $W A$ after 24 hours immersion, had a lower value, 6.2 and $4.4 \%$, respectively.

Direct effect of cement content on mechanical properties of manufactured boards as well as Duncan grouping is presented in Table 4.

By increasing the cement content from 2.5 to 3 times, the bending strength and internal bond in-

Table 3 Direct effect of board type on physical properties and Duncan grouping

Tablica 3. Utjecaj vrste ploče na fizikalna svojstva i grupiranje prema Duncanovu testu

\begin{tabular}{|c|c|c|c|}
\hline Type board / Vrsta ploče & $\begin{array}{c}\text { Reinforced with steel nets } \\
\text { Ploča ojačana čeličnom } \\
\text { mrežom }\end{array}$ & $\begin{array}{c}\text { Reinforced with hemp yarns } \\
\text { Ploča ojačana tkanom } \\
\text { konopljom }\end{array}$ & $\begin{array}{c}\text { Non-reinforced } \\
\text { (control) } \\
\text { Ploča koja nije ojačana }\end{array}$ \\
\hline TS 2h \% & $1.5^{\mathrm{A}}$ & $1.82^{\mathrm{C}}$ & $1.7^{\mathrm{B}}$ \\
\hline TS 24h, \% & $2.42^{\mathrm{A}}$ & $2.60^{\mathrm{AB}}$ & $2.58^{\mathrm{B}}$ \\
\hline WA 2h, \% & $7.86^{\mathrm{A}}$ & $8.99^{\mathrm{B}}$ & $8.99^{\mathrm{B}}$ \\
\hline WA 24h, \% & $15.59^{\mathrm{A}}$ & $16.41^{\mathrm{B}}$ & $16.3^{\mathrm{B}}$ \\
\hline
\end{tabular}

TS $2 \mathrm{~h}$ - thickness swelling after 2 hours immersion in water / debljinsko bubrenje nakon 2 sata namakanja uzoraka u vodi; TS 24h - thickness swelling after 24 hours immersion in water / debljinsko bubrenje nakon 24 sata namakanja uzoraka u vodi, WA $2 \mathrm{~h}$ - water absorption after 2 hours immersion in water / apsorpcija vode nakon 2 sata namakanja uzoraka $u$ vodi; WA $24 \mathrm{~h}$ - water absorption after 24 hours immersion in water / apsorpcija vode nakon 2 sata namakanja uzoraka $u$ vodi.

Table 4 Direct effect of cement content on mechanical properties and Duncan grouping

Tablica 4. Utjecaj sadržaja cementa na mehanička svojstva i grupiranje prema Duncanovu testu

\begin{tabular}{|l|c|c|c|}
\hline Cement content (to dried wood mass) & $\mathbf{2 . 5}$ times & $\mathbf{2 . 7 5}$ times & $\mathbf{3}$ times \\
Sadržaj cementa (u odnosu prema suhoj masi drvnog materijala) & 2,5 puta & 2,75 puta & 3 puta \\
\hline Internal bond strength, MPa / Unutarnja čvrstoća vezanja, MPa & $0.32^{\mathrm{C}}$ & $0.38^{\mathrm{B}}$ & $0.43^{\mathrm{A}}$ \\
\hline Bending strength, MPa / Čvrstoća na savijanje, MPa & $10.23^{\mathrm{C}}$ & $11.38^{\mathrm{B}}$ & $11.54^{\mathrm{A}}$ \\
\hline Modulus of elasticity, MPa / Modul elastičnosti, $M P a$ & $2508.30^{\mathrm{C}}$ & $2638.94^{\mathrm{A}}$ & $2568.07^{\mathrm{B}}$ \\
\hline
\end{tabular}

Table 5 Direct effect of cement content on physical properties and Duncan grouping

Tablica 5. Utjecaj sadržaja cementa na fizikalna svojstva i grupiranje prema Duncanovu testu

\begin{tabular}{|c|c|c|c|}
\hline $\begin{array}{c}\text { Cement content (to dried wood mass) } \\
\text { Sadržaj cementa (u odnosu prema suhoj masi } \\
\text { drvnog materijala) }\end{array}$ & $\begin{array}{c}\mathbf{2 . 5} \text { times } \\
2,5 \text { puta }\end{array}$ & $\begin{array}{c}\mathbf{2 . 7 5} \text { times } \\
2,75 \text { puta }\end{array}$ & $\begin{array}{c}\mathbf{3} \text { times } \\
3 \text { puta }\end{array}$ \\
\hline TS 2h \% & $1.88^{\mathrm{C}}$ & $1.65^{\mathrm{B}}$ & $1.49^{\mathrm{A}}$ \\
\hline TS 24h, \% & $3.21^{\mathrm{C}}$ & $2.15^{\mathrm{AB}}$ & $1.88^{\mathrm{A}}$ \\
\hline WA 2h, \% & $8.29^{\mathrm{B}}$ & $8.56^{\mathrm{B}}$ & $7.79^{\mathrm{A}}$ \\
\hline WA 24h, \% & $17.18^{\mathrm{C}}$ & $15.73^{\mathrm{B}}$ & $14.95^{\mathrm{A}}$ \\
\hline
\end{tabular}

TS $2 \mathrm{~h}$ - thickness swelling after 2 hours immersion in water / debljinsko bubrenje nakon 2 sata namakanja uzoraka u vodi; TS $24 \mathrm{~h}$ - thickness swelling after 24 hours immersion in water / debljinsko bubrenje nakon 24 sata namakanja uzoraka $u$ vodi, WA $2 \mathrm{~h}-$ water absorption after 2 hours immersion in water / apsorpcija vode nakon 2 sata namakanja uzoraka $u$ vodi; WA $24 \mathrm{~h}$ - water absorption after 24 hours immersion in water / apsorpcija vode nakon 2 sata namakanja uzoraka u vodi. 


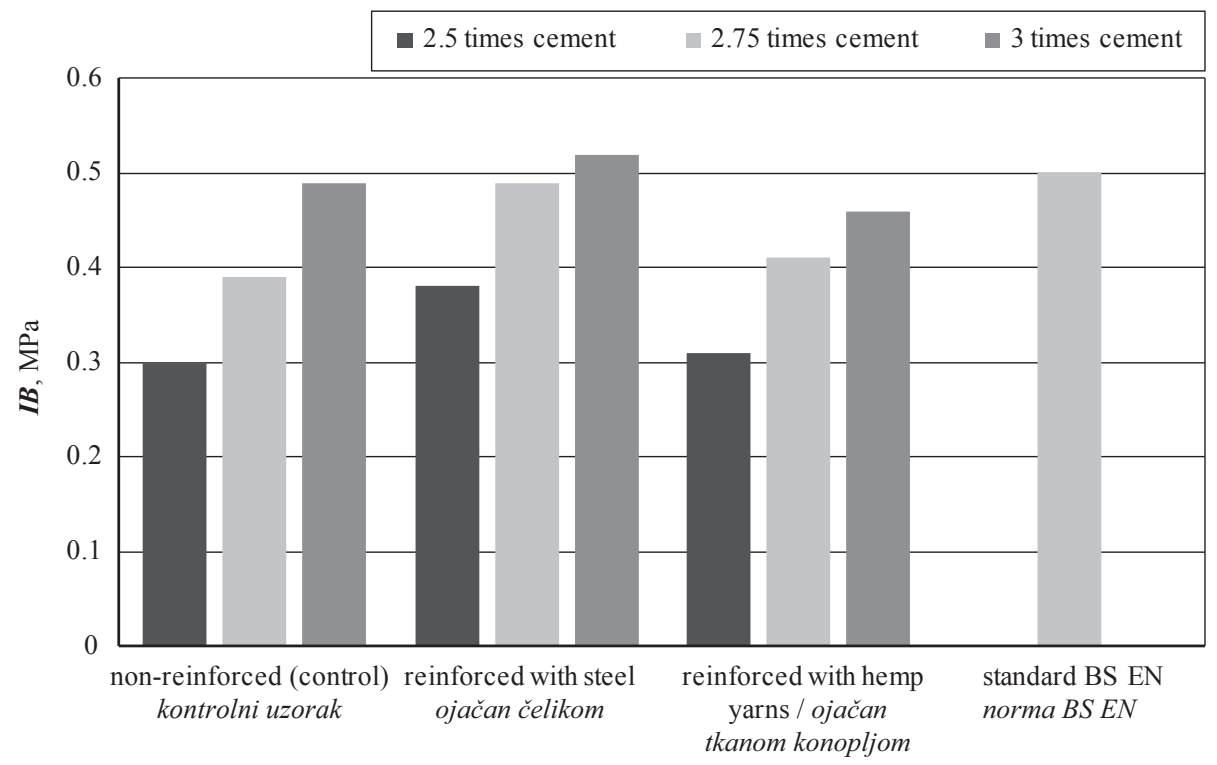

Figure 2 Joint effect of board type and cement content on internal bond strength

Slika 2. Zajednički utjecaj vrste ploče i sadržaja cementa na unutarnju čvrstoću vezanja ploča

creased. Modulus of elasticity only increased by increasing cement content to 2.75 times; the values decreased when the cement content exceeded 2.75.

Direct effect of cement content on physical properties of boards is presented in Table 5 .

The analysis of the effect of cement content on physical properties of boards showed that by increasing the cement content from 2.5 to 3 times to the dry wood mass caused improving water absorption and thickness swelling after 2 and 24 hours immersion in water. Board manufactured with 3:1 cement/wood ratio, in comparison with $2.5: 1$, caused decreasing thickness swelling after 2 and 24 hours immersion in water, 20.7 and $41.4 \%$, respectively. Furthermore, after 2 and
24 hours immersion in water, water absorption decreased by 6 and $13 \%$, respectively.

Table of variance analysis (Table 1) showed that the joint effect of board type and cement content had a significant effect $(P<0.01)$ on mechanical properties (bending strength, modulus of elasticity and internal bond strength).

Figure 2 shows the joint effect of board type and cement content on internal bond strength.

The highest value of internal bond strength was found in boards manufactured with steel nets and 3:1 cement/wood ratio, and it was about $0.52 \mathrm{MPa}$. In comparison with non-reinforced (control) and reinforced with hemp yarns, these boards showed an increased

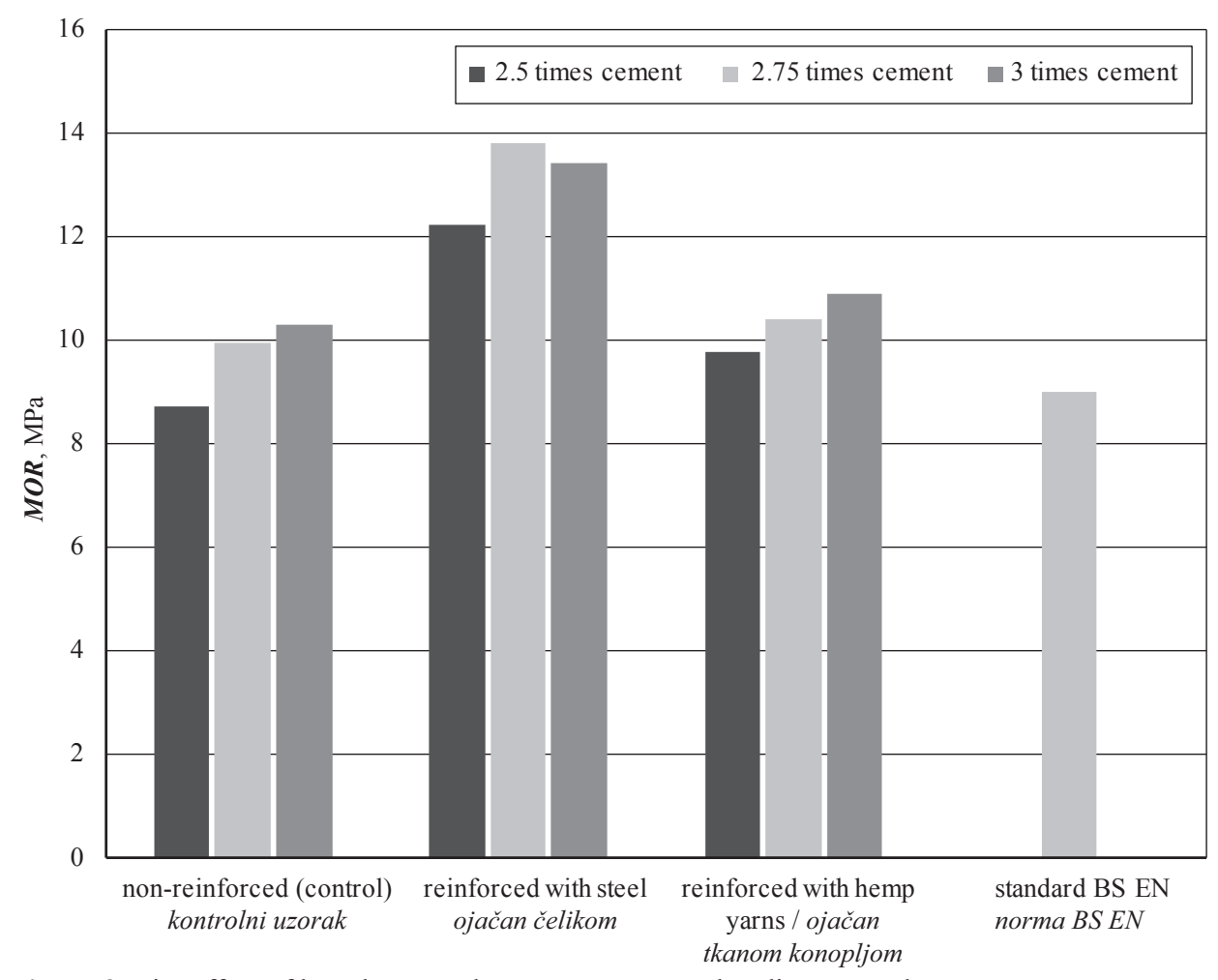

Figure 3 Joint effect of board type and cement content on bending strength

Slika 3. Zajednički utjecaj vrste ploče i sadržaja cementa na čvrstoću ploča na savijanje 


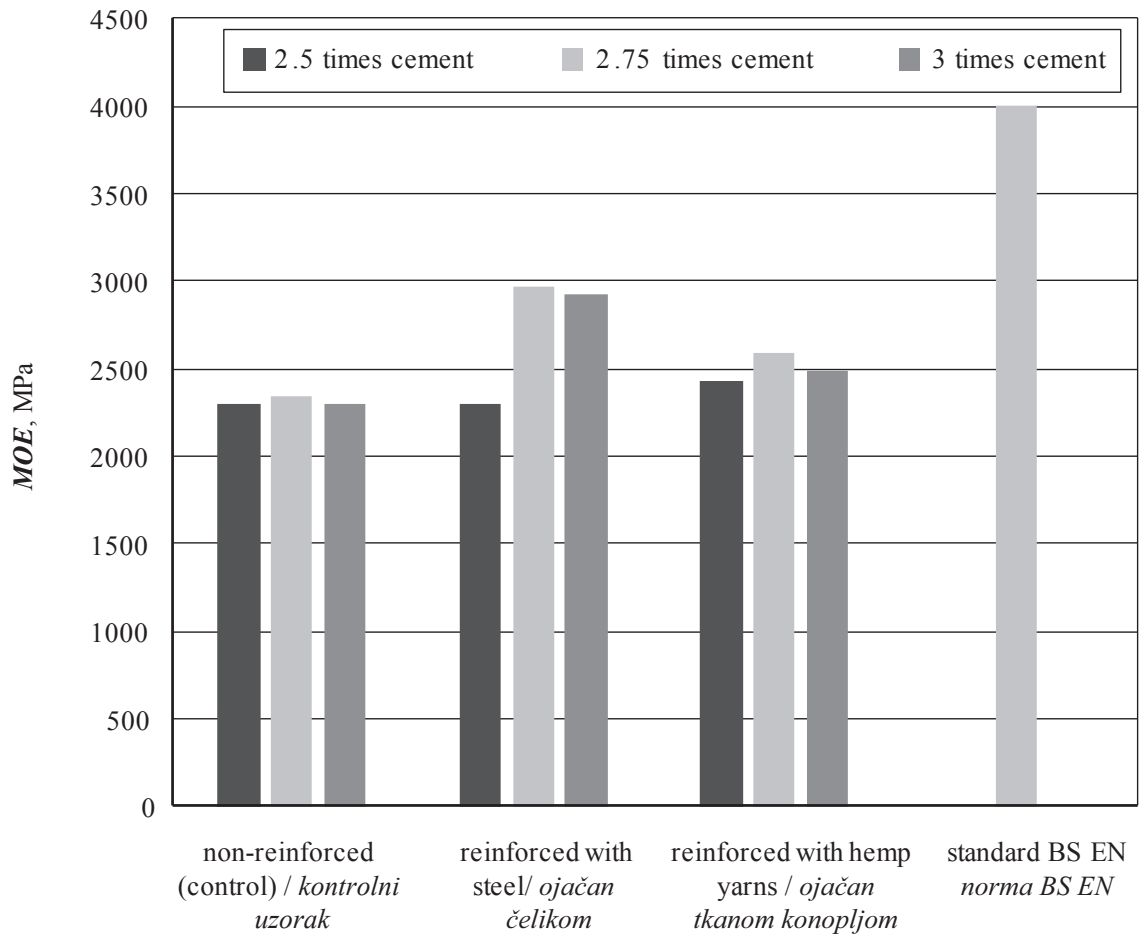

Figure 4 Joint effect of board type and cement content on modulus of elasticity of boards Slika 4. Zajednički utjecaj vrste ploče i sadržaja cementa na modul elastičnosti ploča

internal bond strength with the same cement content $(13 \%)$. The internal bond values of these boards met minimum requirements of wood cement boards of EN 634-2:2007 standard (Figure 2). When the cement content was increased from 2.5 to 3 parts in the cement/ wood ratio, wood particles were closed with cement and the voids between wood particles were filled, resulting in increased internal bond strength of the boards. On the other hand, as hemp yarns have an organic-base, they cannot achieve a good bonding with cement, which causes lower internal bond strength in boards reinforced with hemp yarns than in boards reinforced with steel nets.

The joint effect of board type and cement content on bending strength and modulus of elasticity of boards is presented in Figures 3 and 4, respectively.

Boards manufactured with steel nets and 3:1 cement/wood ratio had the highest values of bending strength and modulus of elasticity, 13.81 and 2977 $\mathrm{MPa}$, respectively. In comparison with non-reinforced boards (control), the bending strength of these boards increased by $34 \%$ and modulus of elasticity by $27 \%$, and the bending strength and modulus of elasticity increased by 26.7 and $14.32 \%$, respectively, in comparison with boards reinforced with hemp yarns. The results conducted in this study correspond to the results of reinforcing MDF by Mohebbi et al. (2011).

EN634-2 standard of wood cement boards indicated that the minimum bending strength is about 9 $\mathrm{MPa}$ and of modulus of elasticity $4000 \mathrm{MPa}$. The bending strength of boards reinforced with steel nets was by $53.3 \%$ higher than the standard value, while the modulus of elasticity was by $25 \%$ lower than the standard value.

When a board is under a bending force, the maximum tensile stress occurs on the top surface and the

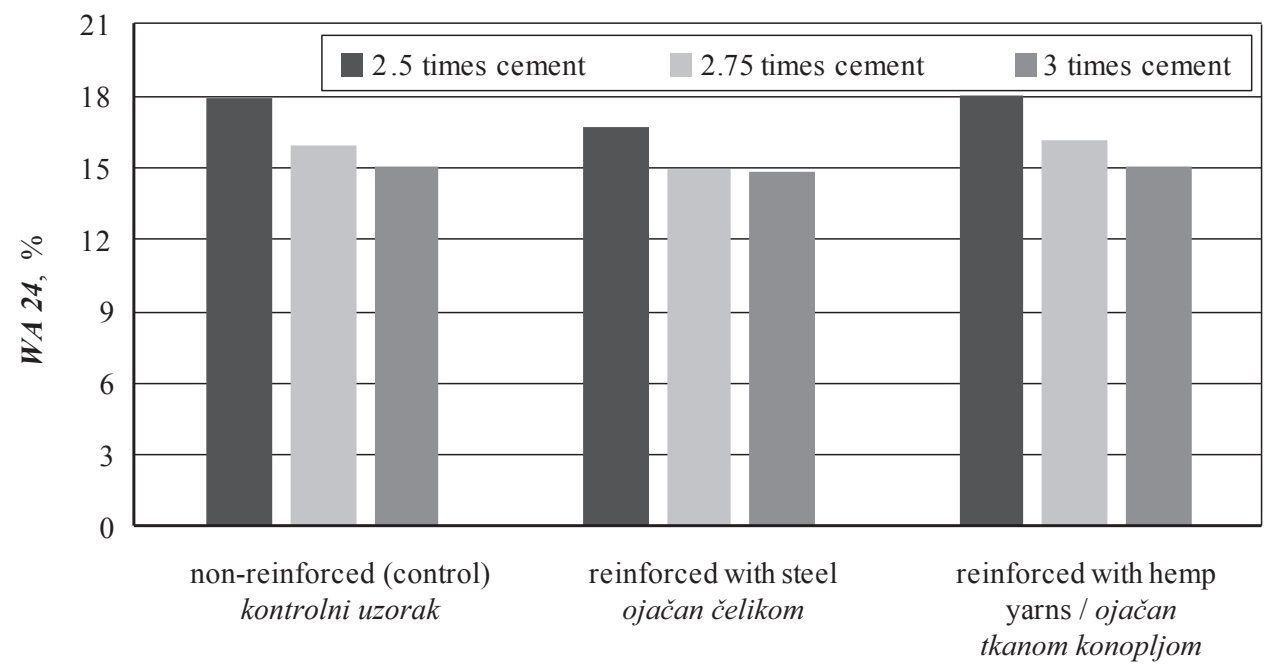

Figure 5 Joint effect of board type and cement content on water absorption

Slika 5. Zajednički utjecaj vrste ploče i sadržaja cementa na apsorpciju vode 


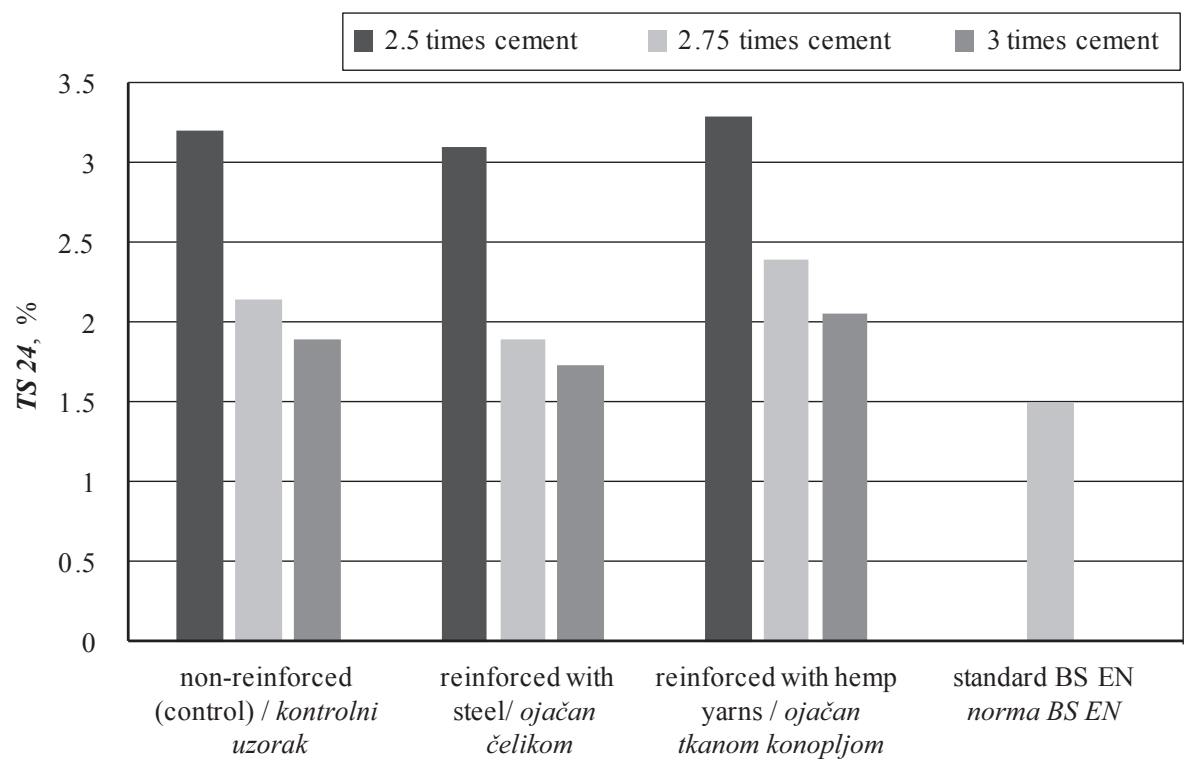

Figure 6 Joint effect of board type and cement content on thickness swelling

Slika 6. Zajednički utjecaj vrste ploče i sadržaja cementa na debljinsko bubrenje ploča

highest compression stress occurs on the bottom surface. Reinforcing boards with steel nets and hemp yarns near the board surfaces increased tensile and compression stresses, and consequently the bending strength and modulus of elasticity increased. Since hardness and stiffness of steel wires and their bonding with cement is higher than that of hemp yarns, boards manufactured with steel nets had higher mechanical strength. When the cement content increased from 2.5 to 3 times in the cement/wood ratio, the voids between wood particles were filled resulting in a strong bond between particles and in the increase of the mechanical strength of boards. The joint effect of board type and cement content on water absorption and thickness swelling after 24 hours immersion in water was significant (Table 1).

Figures 5 and 6 show the joint effect of board type and cement content on water absorption and thickness swelling of boards.

Boards reinforced with steel nets and 3:1 cement/ wood ratio had a minimum thickness swelling and water absorption after 24 hours immersion in water. Results indicated that, when the cement content was increased, wood particles were more effectively covered with cement, and consequently wood particles absorbed less water, so that water absorption and thickness swelling of boards decreased. Good bonding between cement particles and steel wires resulted in improving internal bonding of boards. Consequently, permeability of water into internal layers of boards reinforced with steel nets decreased, meaning that physical properties of boards were improved. Since hemp yarns have a great ability to absorb water, water absorption and thickness swelling of boards reinforced with hemp yarns was slightly higher than that of control boards (non-reinforced). As observed in Figure 5, thickness swelling in these boards after 24 hours immersion in water was slightly higher than required by BS EN standard.

\section{CONCLUSION}

4. ZAKLJUČAK

Results of the analysis of the effect of cement content on physical and mechanical properties of wood cement boards showed that the increase of the cement/ wood ratio from 2.5 to 3 times caused the decrease of water absorption and thickness swelling after 2 and 24 hours immersion in water and increase of mechanical strength. Results of the analysis of the effect of board type (non-reinforced, reinforced with steel nets and reinforced with hemp yarns) on physical and mechanical properties of wood cement boards showed that reinforcing boards with steel nets and hemp yarns caused the increase of their mechanical strength, while boards reinforced with steel nets had a lower water absorption and thickness swelling in comparison with the others. Based on the results of this research, it can be concluded that reinforcing wood cement boards with steel nets and using 2.5 cement/wood ratio could improve physical and mechanical properties for internal use, all in accordance with EN 634-2:2007 standard. In this case, only the modulus of elasticity was lower than the standard value.

\section{Acknowledgement}

This work was supported by Shahid Rajaee Teacher Training University under contract No. 18630".

\section{REFERENCES}

5. LITERATURA

1. Aggarwal, L. K.; Agrawal, S. P.; Thapliyal, P. C.; Karade, S. R., 2008: Cement-bonded composite boards with arhar stalks. Cement and Concrete Composites, 30: 44-51. https://doi.org/10.1016/j.cemconcomp.2007.07.004.

2. Ashori, A.; Tabarsa, T.; Azizi, Kh.; Mirzabeygi, R., 2011: Wood-wool cement board using mixture of eucalyptus and poplar. Industrial Crops and Products, 34: 11461149. https://doi.org/10.1016/j.indcrop.2011.03.033. 
3. BS EN634-2, 2007: Cement-bonded ParticleboardsSpecifications. Part 2: Requirements for OPC bonded particleboards for use in dry, humid and external conditions.

4. Catarina, P.; Fernando, C. J.; Mark, L.; Jose Maria, F., 2006: Characterizing the setting of cement when mixed with cork, blue gum, or maritime pine, grown in Portugal II: X-ray diffraction and differential thermal analyzes. Journal of Wood Science, 52: 318-324. https://doi.org/10.1007/s10086-005-0775-y.

5. Dimakis, A.; Brightwell, L.; Kerns, J.; Neogi, A.; Robak, G.; Schulner, T.; Smith, J. E., 2006: Reinforced wood product and methods for reinforcing a wood product. United States patent. NO: 20060127633.

6. EN 310, 1999: Wood-based panels - Determination of modulus of elasticity in bending and of bending strength. European committee for standardization.

7. EN 317, 1998: Particleboards and fiberboards - Determination of swelling in thickness after immersion in water. European committee for standardization.

8. EN 319, 1998: Particleboards and fiberboards - Determination of tensile strength perpendicular to the plane of the board. European committee for standardization.

9. Fuwape, J. A.; Fabiyi, J. S.; Osuntuyi. E. O., 2007: Technical assessment of three layered cement-bonded boards produced from wastepaper and sawdust. Waste Management, 27: 1611-1616. https://doi.org/10.1016/j.wasman.2006.09.005.

10. Miller, D. P.; Moslemi, A. A., 1991: Wood-cement composites: Species and heartwood-sapwood effects on hydration and tensile strength. Forest products journal, 41(3): 9-14.
11. Mohebbi, B.; Tavassoli, F.; Kazemi, S., 2011: Mechanical properties medium density fiberboard reinforced with metal and woven synthetic nets. Eur. J. Wood Prod, 69: 199-206. https://doi.org/10.1007/s00107-010-0412-3.

12. Nazerian M.; Sadeghiipanah, V., 2013: Cement-bonded particleboard with a mixture of wheat straw and poplar wood. Journal of Forestry Research, 24(2): 381-390. https://doi.org/10.1007/s11676-013-0363-8.

13. Vaickelionis, G.; Vaickelioniene, R., 2006: Cement hydration in the presence of wood extractives and pozzolan mineral additives. Ceramics Silikaty, 50(2): 115-122.

14. Xiong, G., 1996: Steel strip reinforced high-density wood shaving-cement board ribbed roof panel. Cement and Concrete Composites, 18(6): 429-436. https://doi.org/10.1016/S0958-9465(96)00035-2.

15. Wei, Y. M., Guang Zhou, Y.; Tomita, B. J., 2000: Hydration behavior of wood cement-based composite I: evaluation of wood species effects on compatibility and strength with ordinary portland cement. Journal of Wood Science, 46: 296-302. https://doi.org/10.1007/BF00766220.

\section{Corresponding address:}

Assoc. Prof. HOSSEIN RANGAVAR, Ph.D.

Shahid Rajaee Teacher Training University

Faculty of Civil Engineering,

Department of Wood Science and Technology

Tehran, IRAN

e-mail: hrangavar@yahoo.com,rangavar@srttu.edu 